\title{
Csontanyagcsere felnőtt phenylketonuriás pácienseknél - hazai adatok
}

\author{
Barta András Gellért oh. - Sumánszki Csaba dr. - Reismann Péter dr.
}

Semmelweis Egyetem, Általános Orvostudományi Kar, II. Belgyógyászati Klinika, Budapest

\begin{abstract}
Bevezetés: Nemzetközi irodalmi adatokból ismert, hogy a phenylketonuriás páciensek csontsűrűsége csökkent az egészséges populációhoz képest, ennek hátterében számos tényező állhat. Magyarországon mindeddig nem történt átfogó felmérés a felnőtt betegek csontanyagcseréjéről.

Célkitüzés: Vizsgálatunk célja volt felmérni a korán kezelt, hazai felnőtt phenylketonuriás betegek csontsűrüségének időbeli változását a metabolikus kontroll függvényében.

Módszer: Monocentrikus kutatásunkban négyéves intervallumban ismételten mértük 59 felnőtt páciens csontsűrűségét kettős energiájú röntgenabszorpciometria módszerével a combnyakon és a lumbalis csigolyán. A diétahúséget a vér átlagos fenilalanin-, tirozin-szintjei és ezek hányadosa alapján határoztuk meg, majd a fenil-alanin-szintek alapján két alcsoportot alakítottunk ki. Vizsgáltuk a csontsűrűség és az átlagos fenilalanin-tirozin közötti összefüggést, illetve összehasonlítottuk a két alcsoport kezdeti csontsűrűségét és változását.

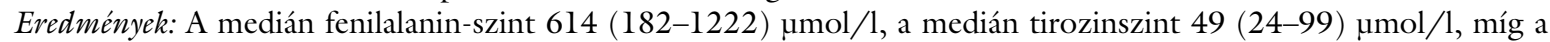
fenilalanin/tirozin arány 16 (4,5-35) volt. A kronológiai korhoz képest alacsony csontsưrúség kilenc páciensnél fordult elő. Az átlagos csontsürüség-változás a combnyakon $+0,0380(-0,1550-0,7800) \mathrm{g} / \mathrm{cm}^{2}$, a lumbalis csigolyán $+0,0120(-0,57300-0,3130) \mathrm{g} / \mathrm{cm}^{2}$ volt. A vér aminosavszintjei, illetve a csontsűrüség változása között korreláció nem volt kimutatható. A diétát jól betartó és a lazább diétát tartó alcsoportok csontsűrúsége között különbséget nem találtunk.

Következtetések: Magyarországon elsőként vizsgáltunk születésüktől kezelt, felnőtt phenylketonuriás betegeket csontsürúség szempontjából. Eredményeinkből arra következtethetünk, hogy fiatal felnőtt korban, pár évre vonatkoztatva érdemi csontvesztés nem jelentkezik, és a metabolikus kontroll szignifikánsan nem befolyásolja a csontsűrüséget. Orv Hetil. 2017; 158(47): 1868-1872.
\end{abstract}

Kulcsszavak: phenylketonuria, csont, csontsűrüség, felnőtt, diéta

\section{Bone metabolism in adults with phenylketonuria - Hungarian data}

Introduction: Patients with phenylketonuria have lower bone mineral density compared to healthy people, however, the ethiology of these alterations is not clear. Hungarian data were missing in this topic.

Aim: The main aim of our study was to survey the correlation between metabolic control and change of bone mineral density in early treated Hungarian adult patients with phenylketonuria.

Method: In this monocentric study bone mineral density of 59 adult PKU patients have been repeatedly measured in a 4-year interval using dual-energy X-ray absorptiometry. Two subgroups have been established based on average blood phenylalanine levels. The correlation between the change in bone mineral density and average phenylalanine, tyrosine concentrations have been determined while initial bone mineral density and change have also been examined in the subgroups.

Results: Mean phenylalanine concentration was 614 (182-1222) micromol/L, whereas mean tyrosine concentration was 49 (24-99) micromol/L and the calculated ratio was 16 (4,5-35). Three patients have had severely decreased bone mineral density in either localisation while 22 have had mild decrease. Low bone mineral density compared to cronological age has been found by 9 patient. The mean change was $+0.0380(-0.1550-0.7800) \mathrm{g} / \mathrm{cm}^{2}$ in femur, and $+0.0120(-0.57300-0.3130) \mathrm{g} / \mathrm{cm}^{2}$ in the lumbar spine. There was a correlation in the change in Z-score neither with mean phenylalanine nor with tyrosine concentration.

Conclusions: Bone mineral density was not changed and hardly influenced by the metabolic control in early-treated young adult phenylketonuria patients in a few years interval. 
Keywords: phenylketonuria, bone, bone mineral density, adult, diet

Barta AG, Sumánszki Cs, Reismann P. [Bone metabolism in adults with phenylketonuria - Hungarian data]. Orv Hetil. 2017; 158(47): 1868-1872.

(Beérkezett: 2017. augusztus 12.; elfogadva: 2017. szeptember 14.)

\begin{abstract}
Rövidítések
$\mathrm{BMD}=($ bone mineral density $)$ csontsűrüség; DEXA = (dual energy X-ray absorptiometry) kettôs energiájú röntgenabszorpciometria; ETPKU = early-treated phenylketonuria; ISCD $=$ International Society of Clinical Densitometry; Phe $=$ fenilalanin; $\mathrm{PKU}=$ phenylketonuria $; \mathrm{SD}=$ standard deviáció $; \mathrm{Tyr}=$ tirozin
\end{abstract}

A phenylketonuria (PKU, OMIM 261600) egy autoszomális, recesszív módon öröklődő, veleszületett anyagcsere-betegség, amely kezeletlen esetekben súlyos neurológiai, pszichiátriai és szomatikus tünetekkel jár. Az utóbbi évtizedekben a kötelező tömegszürésnek, a terápiás lehetőségek bővülésének és a tartós, rendszeres utánkövetésnek köszönhetően a betegek életminősége jelentős mértékben javult. Felnőtt az első olyan PKU-s populáció, amely születésétől fogva szigorú, természetes fehérjében szegény diétát tart, és az aminosav pótlása orvosi tápszerek formájában történik. Ezen PKU-s betegeket az angolszász szakirodalom „early-treated PKU”-nak (ETPKU), azaz korán kezelt PKU-soknak nevezte el. A sikeres kezelés eredményeképpen új kihívások jelentek meg, mint a PKU-s páciensek terhesgondozása, a fenilalanin- (Phe-) mentes aminosavkeverék-alapú terápia hosszú távú metabolikus hatásai, az élethosszig tartó szigorú diéta időskori hatásai, valamint a csontanyagcsere krónikus eltérései [1].

A gyermek és serdülő PKU-s betegek jelentős része alacsonyabb csonttömeggel bír az egészséges, azonos korú és nemú társaikhoz viszonyítva [2-4]. A csökkent csontsűrûség mellé fogászati rendellenességek és kiegyensúlyozatlan csontnövekedés is társulhat [5]. A törési kockázatot mindössze egyetlen kutatás vizsgálta, mely 2,6-szeres kockázatnövekedést talált az egészséges kontrollcsoporthoz képest [6]. Azonban a felnőtt PKUsok csontháztartására vonatkozó nemzetközi irodalom egyelőre elenyésző, ezen közlemények is sokszor egymásnak ellentmondó eredményeket ismertetnek [7-9]. Szintén nem egyértelmű ma még az orvosi tápszerek és a csontsưrüség (BMD) közötti kapcsolat $[10,11]$.

A csontrendszeri szövődmények etiológiája nem tisztázott, hátterében számos tényező oki szerepe felmerült:

1. Primeren a betegség, amely a magas Phe-szint által befolyásolhatja az osteoclastok és osteoblastok múködését [12].

2. A diétahüség csökkenése, hiszen a természetes fehérjében csökkentett restriktív diéta és az orvosi tápsze- rek rendszeres fogyasztása nehéz feladat elé állítja a pácienseket. Zavart szenvedhet a kalcium-, a foszfor-, a D-vitamin-bevitel, illetve szerepet játszhat a túlzott ureagenezis és a szuboptimális aminosav-összetétel is [3, 13-16].

3. Felmerülhet a neurológiai vagy pszichiátriai komplikációkból eredően az egészséges mozgás, sport hiányának oki szerepe is $[17,18]$.

Magyarországon mindeddig nem történt átfogó felmérés a felnőttkorú PKU-s betegek csontanyagcseréjével kapcsolatban. A mostani vizsgálat célja volt felmérni a hazai felnőtt ETPKU-s betegek csontsűrüségét, annak változását többéves perióduson belül, keresni a lehetséges összefüggést a metabolikus kontroll és a csontsűrüség változása között.

\section{Módszer}

Egy retrospektív monocentrikus vizsgálat keretén belül a Semmelweis Egyetem II. Belgyógyászati Klinikáján 2010 és 2016 között fenilalanin-hidroxiláz-defektussal bíró, 25 év feletti PKU-s pácienseket vontunk be, akiknek a vizsgált időszakban minimum két csontsưrüségmérése volt. Kizárási feltétel volt az 1975 előtti születési év, a terhesség, az atípusos PKU diagnózis, daganatos betegség, illetve az adott időperiódusra vonatkozó hiányos dokumentáció. Az eredeti 170 fóből végül 59 beteg eredményeit tudtuk értékelni. A bevonásra került nőbetegeknél érdemi cikluszavar nem volt igazolható.

A kettős energiájú röntgenabszorpciometriás eljárással (DEXA, Delphi W, Hologic Inc., Bedford, MA, Amerikai Egyesült Államok) mért lumbalis csigolya (LILIV) és combnyak BMD-eredményeit értékeltük ki, vizsgáltuk a $\mathrm{Z}$-score-t. A diétahúséget a vér átlagos fenilalanin- (Phe), tirozin- (Tyr) szintjei és a Phe/Tyr hányados alapján határoztuk meg. A jelenlegi irányelv alapján a 14 év feletti PKU-s betegek esetében a vér Phe-koncentrációjának céltartománya 120-600 بmol/1, a vértiroziné 50-100 $\mathrm{mmol} / 1$, míg a Phe:Tyr arány esetében 2,5 alatti érték [19]. Betegeinket Phe-értékeik alapján két csoportra osztottuk $(600 \mu \mathrm{mol} / \mathrm{l}$ alatti átlagértékkel bíró, valamint $600 \mu \mathrm{mol} / \mathrm{l}$ feletti átlagértékkel bíró csoport). Ezt alapul véve a vizsgált időszakban 28 páciens átlagos Phe-koncentrációja esett a céltartományon belülre (első csoport), míg 31 fó a céltartománynál magasabb Phe-szinttel rendelkezett (második csoport). A csontsűrüségmérés eredményét a WHO és az 
ISCD-ajánlás alapján értékeltük $[20,21]$. A statisztikai elemzéseket GraphPad Prism 7.02 (GraphPad Software, Inc., La Jolla, CA, Amerikai Egyesült Államok) programcsomaggal végeztük. A csontsưrüség és az átlagos Phe-, Tyr-koncentrációk, illetve Phe/Tyr hányados közötti összefüggés vizsgálatára Spearman-féle rangkorrelációt használtunk. A csoportok között a súlyos, enyhén súlyos, illetve normális csontsűrüség előfordulásának összehasonlítását Fisher-féle egzakt teszttel végeztük. Az eloszlások vizsgálatához Shapiro-Wilk-tesztet használtunk. A csoportok közötti csontsưrüség változását nem normális eloszlás miatt Mann-Whitney-próbát használva hasonlítottuk össze. A szignifikanciát $p<0,05$ jelentette. Mivel a populáció nem mutatott normális eloszlást, ezért a demográfiai értékeket mediánként adtuk meg, zárójelben megjelölve a minimum- és maximumértékeket.

\section{Eredmények}

Az 59 páciens nemi megoszlása 34 nő és 25 férfi volt. A betegek medián életkora a vizsgálat kezdetén 34 (2541) év volt. A medián Phe-szint 614 (182-1222) umol/1, a medián Tyr-szint 49 (24-99) $\mu \mathrm{mol} / 1$, míg a Phe/Tyr arány 16 (4,5-35) volt. Az egyes csoportok demográfiai megoszlását az 1 . táblázat mutatja.

1. táblázat | Demográfiai adatok és aminosavvérszintek csoportokra lebontva. Általános adatok

\begin{tabular}{|c|c|c|c|}
\hline & $\begin{array}{l}\text { Első csoport (Phe } \\
\text { céltartományban) }\end{array}$ & $\begin{array}{l}\text { Második csoport } \\
\text { (céltartomány } \\
\text { feletti Phe) }\end{array}$ & p-Érték \\
\hline Betegszám & 28 & 31 & \\
\hline $\begin{array}{l}\text { Nemi megoszlás } \\
(\mathrm{F} / \mathrm{N})\end{array}$ & $9 / 19$ & $15 / 16$ & 0,1879 \\
\hline $\begin{array}{l}\text { Átlagos életkor } \\
\text { (év) }\end{array}$ & $33(25-40)$ & $34(25-41)$ & 0,4656 \\
\hline $\begin{array}{l}\text { Átlagos Phe } \\
(\mu \mathrm{mol} / 1)\end{array}$ & $\begin{array}{l}506,4 \\
(181,8-598,7)\end{array}$ & $\begin{array}{l}779 \\
(606,9-1222)\end{array}$ & $<0,0001$ \\
\hline $\begin{array}{l}\text { Átlagos Tyr } \\
(\mu \mathrm{mol} / 1)\end{array}$ & $\begin{array}{l}58,30 \\
(29,30-99,47)\end{array}$ & $\begin{array}{l}41,47 \\
(24,48-89,55)\end{array}$ & 0,0027 \\
\hline Phe/Tyr arány & $\begin{array}{l}9,230 \\
(4,586-20,64)\end{array}$ & $\begin{array}{l}20,14 \\
(9,041-35,43)\end{array}$ & $<0,0001$ \\
\hline
\end{tabular}

$\mathrm{F}=$ férfi $\mathrm{N}=$ nö; Phe $=$ fenilalanin $; \mathrm{Tyr}=$ tirozin

A csontsűrüséget a vizsgált időszakban két alkalommal határoztuk meg, a két mérés között eltelt átlagos idő 3,32 év volt. Csonttörés nem volt. Az ISCD-ajánlás alapján a kronológiai korhoz képest alacsony csontsürüség (Z-score <-2,0 SD) kilenc páciensnél (13\%) fordult elő. $\mathrm{Az}$ átlagos csontsúrúség-változás a combnyakon $+0,0380$ $(-0,1550-0,7800) \mathrm{g} / \mathrm{cm}^{2}$, a lumbalis csigolyán $+0,0120$ $(-0,57300-0,3130) \mathrm{g} / \mathrm{cm}^{2}$ volt. Spearman-féle rangkorrelációs vizsgálattal nem találtunk korrelációt a vér ami- nosavszintjei (Phe, Tyr), illetve a csontsưrüség változása (Z-score) között sem a combcsont, sem a lumbalis csigolya esetében (2. táblázat).

2. táblázat $\mid$ Phe-, Tyr-, Phe/Tyr értékek, valamint a csontsưrúség-változás közötti összefüggés $r$ - és $p$-értékei. (Szignifikáns, ha $p<0,05$ )

Femur

\begin{tabular}{lcc}
\hline & $r$ & $p$ \\
\hline Phe & 0,05681 & 0,6691 \\
Phe/Tyr & $-0,1482$ & 0,2626 \\
Tyr & 0,1069 & 0,4202 \\
\hline
\end{tabular}

Lumbalis csigolya

\begin{tabular}{lcc}
\hline & $r$ & $p$ \\
\hline Phe & $-0,05705$ & 0,6678 \\
Phe/Tyr & $-0,08502$ & 0,5220 \\
Tyr & 0,05179 & 0,6969 \\
\hline
\end{tabular}

$\mathrm{Az}$ 1. és 2. ábra a jól diétázó első csoport és a diétát kevésbé jól tartó második csoport Z-score-változását mutatja be a lumbalis csigolyán és a femuron. A két csoport Z-score-változása között nem találtunk szignifikáns különbséget. A femur esetében a p-érték 0,9291-nek, míg a lumbalis csigolya esetében 0,3842-nek adódott (3. táblázat).

\section{Megbeszélés}

A csontsưrüség vizsgálatára két származtatott érték terjedt el. A T-score alkalmazása gyermekek és fiatal felnőttek esetében félrevezető lehet, csak azután érdemes használni, amikor már fellépett érdemi csontvesztés. Fiatal páciensek esetében ezért Z-score-t számítunk, amely megadja, hogy hány standard deviációval tér el a páciens csontsűrüsége (BMD) az adott korban és nemben mért átlagtól. Az ISCD ajánlása szerint a -2 alatti Z-score-t a kronológiai korhoz képest alacsonynak nevezzük, osteoporosist pedig csak pozitív törési anamnézis esetén állapíthatunk meg [21].

Kutatásunk eredménye alapján fiatal felnőtt phenylketonuriás betegek $42 \%$-ában a csontsưrüség csökkent az azonos korú és nemú, egészséges populációhoz képest, amelyből $5 \%$ súlyosan csökkent és $37 \%$ csökkent csontsürüségü páciens volt.

A -1 és -2,5 közötti Z-score prevalenciája phenylketonuriában nemzetközi adatok szerint 28-46\%-os, míg -2,5 alatti Z-score 5-14\% körüli gyakorisággal fordul elő [1, 8, 22]. A nemzetközi közlemények alapján a betegek körülbelül 10\%-a rendelkezik -2 alatti, vagyis a kronológiaihoz képest alacsony csontsűrüséggel [1]. Magyarországon kevéssel nagyobb arányban (13\%) találtunk ilyen pácienseket. Ezek alapján a hazai eredmények a nemzetközi irodalomban közölt megoszlásokhoz hasonlóak. 


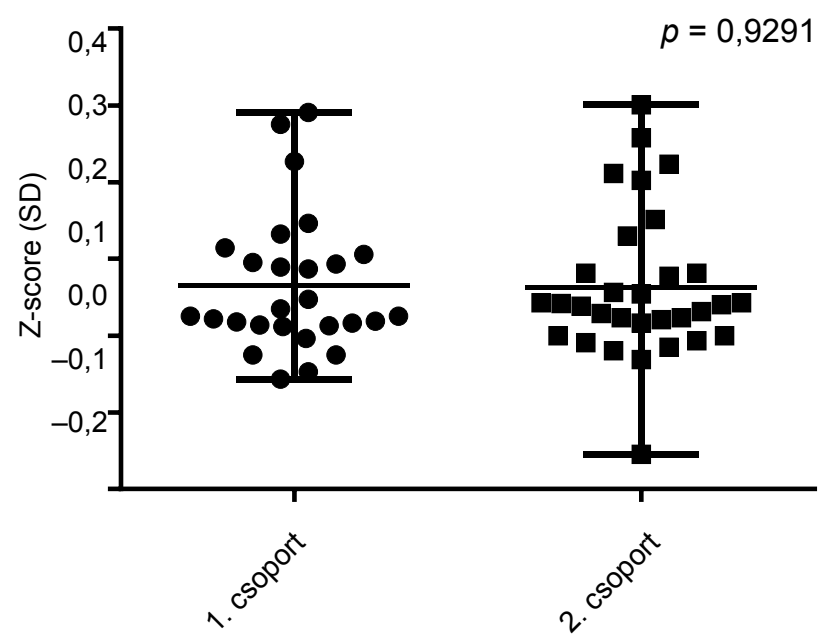

1. ábra $\quad$ A femur denzitásváltozása a két csoportban

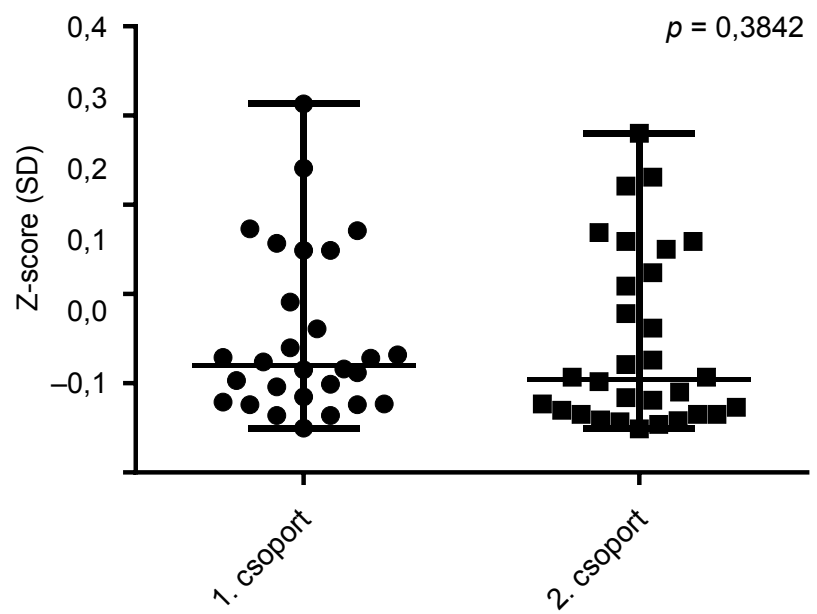

2. ábra |A lumbalis csigolya denzitásváltozása a két csoportban

3. táblázat $\mid$ Z-score-változás a két betegcsoport esetében. Szignifikáns a két csoport közötti különbség, ha a $p$-érték $<0,05$

\begin{tabular}{llll}
\hline & Első csoport & Második csoport & $p$-Érték \\
\hline Femur & 0,0300 & 0,0400 & 0,9291 \\
& $(-0,0570-0,7800)$ & $(-0.1550-0,3010)$ & \\
\hline $\begin{array}{l}\text { Lumbalis } \\
\text { csigolya }\end{array}$ & 0,0200 & 0,0020 & 0,3842 \\
\hline
\end{tabular}

Osteoporosist a hiányzó csonttörési anamnézis alapján nem igazoltunk.

A csontsűrúség változása nem mutatott összefüggést a vér Phe/Tyr szintjével és e kettő aminosavarányával. Ebből arra következtethetünk, hogy felnőtttkorban pár évet vizsgálva, a metabolikus kontroll érdemben nem befolyásolja a csontsúrúséget. Ezt támasztja alá, hogy a jól diétázó csoport és a lazább diétát tartó csoport között nem mutatkozott különbség a csontsűrúség-változás szempontjából. Az elmúlt években megjelent közlemények gyermek vagy fiatal felnőtt PKU-s betegekkel nem tudták megerősíteni a korábbi vélekedést, hogy a magas vér-Phe-szint szoros összefüggést mutat a csökkent csontsưrúség kialakulásával $[9,22]$. Eredményünk ebbe a trendbe illeszthetô be.

Bár az általunk vizsgált, születésüktől kezelt, fiatal felnőtt PKU-s betegpopuláció átlagos vér Phe-koncentrációja kevéssel volt a céltartomány felső határa felett (614 $\mu \mathrm{mol} / \mathrm{l})$, a magyar betegek több mint fele (53\%) nem tartja kellően fegyelmezetten a diétát. Ennek rövid távú kihatása a csontsűrűségre nem volt igazolható, azonban neurokognitív káros hatása már ismert [23].

A vizsgálat számos korláttal rendelkezik, amelyeket figyelembe kell venni az eredmények értékelése során. A csont metabolizmusa és felépítése egy összetett szabályozás alapján múködő rendszer, amelyekből tanulmányunk számos tényező́t nem vizsgált, viszont szükségesek a betegség megértéséhez. Pontosabb képet kaphatnánk a csontanyagcsere-markerek, az élethossz vér Phe-szint ismeretében, valamint csontbiopszia során nyert mikrostruktúra analízisét követően. A diétahûséget vér Phe-szint alapján határoztuk meg, de diétásnapló vezetése és elemzése pontosabb képet adott volna róla. Ismert, hogy a fizikai aktivitás jelentős mértékben befolyásolni képes a csontanyagcserét és -sứrúséget, amelyet ez a tanulmány nem vizsgált.

A PKU ritka betegség, így nagyszámú betegpopulációval bíró tanulmány nem várható. Mivel nincs speciális, PKU-ra vonatkozó osteoporosisprevenciós és -kezelési stratégia, így az általános, széles körben ismert prevenció alkalmazható ebben a betegcsoportban is [24].

Elsőként vizsgáltunk születésüktől kezelt, felnőtt PKU-s betegeket Magyarországon a csontsűrúség szempontjából. Mindeddig nem álltak rendelkezésre hazai adatok PKU-s felnőttek csontsứrúségére vonatkozóan. Az adatok további gyưjtése, időszakos vizsgálata lehetô" vé teszi ezen első ETPKU-generáció hosszú távú követését, hogy az esetleges időskori szövődményekre (például az esetlegesen menopausa során fellépő további csontvesztésre) felkészülhessünk, azokat időben felderíthessük.

Anyagi támogatás: A közlemény megírása, illetve a kapcsolódó kutatómunka anyagi támogatásban nem részesült.

Szerzôi munkamegosztás: B. A. G.: A kézirat megszövegezése, az irodalom összeállítása. S. Cs.: A kézirat megszövegezése. R. P.: Az összefoglaló kialakításában való meghatározó részvétel, a cikk végleges formájának megvalósítása. A cikk végleges változatát valamennyi szerző elolvasta és jóváhagyta.

Érdekeltségek: A szerzőknek nincsenek érdekeltségeik. 


\section{Irodalom}

[1] Demirdas S, Coakley KE, Bisschop PH, et al. Bone health in phenylketonuria: a systematic review and meta-analysis. Orphanet J Rare Dis. 2015; 10: 17.

[2] Adamczyk P, Morawiec-Knysak A, Płudowski P, et al. Bone metabolism and the muscle-bone relationship in children, adolescents and young adults with phenylketonuria. J. Bone Miner Metab. 2011; 29: 236-244.

[3] Hillman L, Schlotzhauer C, Lee D, et al. Decreased bone mineralization in children with phenylketonuria under treatment. Eur J Pediatr. 1996; 155(Suppl): S148-S152.

[4] Lewiecki EM, Watts NB. New guidelines for the prevention and treatment of osteoporosis. South Med J. 2009; 102: 175-179.

[5] Porta F, Mussa A, Zanin A, et al. Impact of metabolic control on bone quality in phenylketonuria and mild hyperphenylalaninemia. J Pediatr Gastroenterol Nutr. 201 1; 52: 345-350.

[6] Greeves LG, Carson DJ, Magee A, et al. Fractures and phenylketonuria. Acta Paediatr. 1997; 86: 242-244.

[7] Barat P, Barthe N, Redonnet-Vernhet I, et al. The impact of the control of serum phenylalanine levels on osteopenia in patients with phenylketonuria. Eur J Pediatr. 2002; 161: 687-688.

[8] Modan-Moses D, Vered I, Schwartz G, et al. Peak bone mass in patients with phenylketonuria. J Inherit Metab Dis. 2007; 30: 202-208.

[9] De Groot MJ, Hoeksma M, Van Rijn M, et al. Relationships between lumbar bone mineral density and biochemical parameters in phenylketonuria patients. Mol Genet Metab. 2012; 105: 566-570.

[10] Zeman J, Bayer M, Stepán J. Bone mineral density in patients with phenylketonuria. Acta Paediatr. 1999; 88: 1348-1351.

[11] Coakley KE, Douglas TD, Singh RH. Using predictive modeling to estimate bone mineral density in children and adults with phenylketonuria. Osteoporos Int. 2013; p. S431-S432.

[12] Porta F, Roato I, Mussa A, et al. Increased spontaneous osteoclastogenesis from peripheral blood mononuclear cells in phenylketonuria. J Inherit Metab Dis. 2008; 31: 339-342.

[13] Nagasaka H, Tsukahara H, Takatani T, et al. Cross-sectional study of bone metabolism with nutrition in adult classical phenylketonuric patients diagnosed by neonatal screening. J Bone Miner Metab. 2011; 29: 737-743.
[14] Pérez-Dueñas B, Cambra FJ, Vilaseca M, et al. New approach to osteopenia in phenylketonuric patients. Acta Paediatr. 2002; 91: 899-904.

[15] Van Calcar SC, MacLeod EL, Gleason ST, et al. Improved nutritional management of phenylketonuria by using a diet containing glycomacropeptide compared with amino acids. Am J Clin Nutr. 2009; 89: 1068-1077.

[16] Deglaire A, Fromentin C, Fouillet H, et al. Hydrolyzed dietary casein as compared with the intact protein reduces postprandial peripheral, but not whole-body, uptake of nitrogen in humans. Am J Clin Nutr. 2009; 90: 1011-1022.

[17] Strope MA, Nigh P, Carter MI, et al. Physical activity-associated bone loading during adolescence and young adulthood is positively associated with adult bone mineral density in men. Am J Mens Health 2015; 9: 442-450.

[18] Tveit M, Rosengren BE, Nilsson JA, et al. Exercise in youth: High bone mass, large bone size, and low fracture risk in old age. Scand J Med Sci Sports 2015; 25: 453-461.

[19] Camp KM, Parisi MA, Acosta PB, et al. Phenylketonuria Scientific Review Conference: State of the science and future research needs. Mol Genet Metab. 2014; 112: 87-122.

[20] Kanis JA, Melton LJ 3rd., Christiansen C, et al. The diagnosis of osteoporosis. J Bone Miner Res. 1994; 9: 1137-1141

[21] International Society for Clinical Densitometry. 2015 Official positions - adult. Available from: http://www.iscd.org/officialpositions /2015-iscd-official-positions-adult/ [accessed: July 16, 2017].

[22] Lage S, Bueno M, Andrade F, et al. Fatty acid profile in patients with phenylketonuria and its relationship with bone mineral density. J Inherit Metab Dis., 2010; 33(Suppl 1): S363-S371.

[23] Van Spronsen F J, van Wegberg J, Ahring K, et al. Key European guidelines for the diagnosis and management of patients with phenylketonuria. Lancet Diab Endocrinol. 2017; 9: 743-756.

[24] Cosman F, de Beur SJ, LeBoff MS, et al. Clinician's guide to prevention and treatment of osteoporosis. Osteoporos Int. 2014; 25 : 2359-2381

(Reismann Péter dr., Budapest, Szentkirályi u. 46., 1088 e-mail: reismann.peter@med.semmelweis-univ.hu)

\title{
MEGHÍVó
}

\section{A Szent János Kórház és Észak-budai Egyesített Kórházak Tudományos Bizottsága} tisztelettel meghívja az érdeklődőket a következő tudományos ülésére, melyet a kórház I. Belgyógyászati és Gasztroenterológiai Osztálya és a Magyar Gasztroenterológiai Társaság rendez.

\author{
Időpont: 2017. december 7. (csütörtök) 14.00 óra \\ Helyszín: Szent János Kórház Auditóriuma - 1125 Budapest, Diós árok 1-3. \\ Téma: Aktualitások a gasztroenterológiában
}

Üléselnök: Dr. Székely György és Dr. Lukovich Péter

\section{Előadások:}

Dr. Székely György: Dr. Siket Ferenc (1952-2017) - Egy igaz ember

Dr. Lukovich Péter: Colitis ulcerosa súlyos formája - nem szokványos mütéti megoldás

Dr. Tóth Gábor Tamás: A minőségi colonoscopia mutatói

Dr. Kovács Márta: Felnőttkori coeliakia - a diagnosztika csapdái

Dr. Lieber Rita: Gyulladásos bélbetegség ritka szövődményei

10 perc

15 perc

15 perc

10 perc

10 perc

\section{BÜFÉ}

Minden érdeklődőt szeretettel várunk! 